\title{
Serum Immunoglobulins and IgG Subclasses in SS Patients with Saudi Arabia/India Haplotype
}

\author{
A.D. Adekile ${ }^{\text {a }} \quad$ M.Z. Haider ${ }^{\text {a }} \quad$ F. Serebour ${ }^{b} \quad$ K. Al-Zaabic ${ }^{\text {C. M. Tulic }}$ \\ Departments of a Pediatrics and ${ }^{\mathrm{b}}$ Microbiology, Faculty of Medicine, Kuwait University, \\ 'Department of Nuclear Medicine, Mubarak Al-Kabeer Hospital, Kuwait
}

\section{Key Words}

Serum immunoglobulins $\cdot \lg G$ subclasses .

Sickle cell anemia. Saudi Arabia/India

haplotype Spleen function

\begin{abstract}
Objectives: This study investigates serum immunoglobulin fractions (lgG, $\lg A$ and $\lg M$ ) and IgG subclasses (IgGScs; IgG1-4) in SS patients with the Saudi Arabia/India (SAI) haplotype. The influence of gender, $\mathrm{Hb} \mathrm{F}$ levels, spleen function and coexistent $\alpha$-thal trait were studied. Methods: Immunoglobulins and IgGScs were assayed using nephelome-

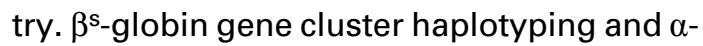
globin genotyping were done using a combination of PCR and allele-specific oligonucleotide hybridization techniques. Results: Twenty-nine steady-state (i.e. not acutely ill) SS patients (23 SAl homozygotes and $6 \mathrm{SAl} /$ Benin compound heterozygotes) and 34 healthy age- and sex-matched $\mathrm{Hb}$ AA and AS
\end{abstract}

\begin{tabular}{ll}
\hline KARGER & (1) 1999 S. Karger AG, Basel \\
Fax +4161306 1234 & \\
$\begin{array}{l}\text { E-Mail karger@karger.ch } \\
\text { www.karger.com }\end{array}$ & $\begin{array}{l}\text { Accessible online at: } \\
\text { http://BioMedNet.com/karger }\end{array}$
\end{tabular}

controls were studied. Mean serum IgG and $\lg$ A values were significantly higher in the patient group, while there were no significant differences in the mean IgGScs. The patient group was further subdivided depending on whether the spleen was normally visualized (group 1), partially visualized (group 2) or not visualized (group 3) on ${ }^{99 \mathrm{mTc}} \mathrm{T}$-labeled tin colloid scintigraphy. There was a significant sequential increase in mean IgG values from group 1 to group 3 but the reverse was true for IgM, while IgA showed no consistent trend. The mean levels of $\lg G 1$ and $\lg G 3$ were significantly higher in group $3(\mathrm{p}<$ 0.01). Hb F level did not influence immunoglobulins or IgGScs, but SS patients with coexistent $\alpha$-thal trait tended to have lower $\lg \mathrm{G}$ and $\lg \mathrm{G} 1$ levels. Conclusions: Increased serum $\lg$ is associated with poor splenic function and recurrent infections among SAI patients, while increased IgM is seen mainly in those with relatively normal splenic function.

Prof. Adekunle D. Adekile

Department of Pediatrics, Faculty of Medicine, Kuwait University PO Box 24923, Safat 13110 (Kuwait)

Tel. +965 5391486, Fax +965 5338940

E-Mail adekile@hsc.kuniv.edu.kw 


\section{Introduction}

Elevations of one or more of the different serum immunoglobulin fractions (IgG, IgA and $\operatorname{IgM}$ ) have been reported in SS patients. This is due to reticuloendothelial stimulation from hematopoietic stress and recurrent infections. A direct relationship has been found between immunoglobulin levels (especially $\mathrm{IgG}$ and $\mathrm{IgM}$ ) and spleen size and function [1-8]. However, most studies were carried out on American [1], Jamaican [2] or African [6, $8]$ patients who tend to have the severe variants $[9,10]$ of the disease (Benin and Bantu haplotypes with low $\mathrm{Hb} \mathrm{F}$ ). Studies of patients with the milder Saudi Arabia/India (SAI) haplotype (high $\mathrm{Hb} \mathrm{F}$ ) have been few [3]. Also, there is a paucity of information on IgG subclasses (IgGScs) in SS patients in general. We have quantitated immunoglobulin and IgGSc levels in a group of SS patients in Kuwait and correlated the results with age, sex, $\mathrm{Hb}$ F level, coexistent $\alpha$-thal trait, spleen size and function.

\section{Materials and Methods}

The subjects were steady-state (i.e. not acutely ill) SS patients being followed up in the Pediatric Hematology Clinics of the Mubarak Al-Kabeer and the Al Amiri Hospitals in Kuwait. The diagnosis had been established from $\mathrm{Hb}$ electrophoresis, $\mathrm{Hb}$ quantitation using cation-exchange HPLC and family studies. Informed consent was obtained from the parents of all patients. A control group made up of apparently healthy $\mathrm{Hb} \mathrm{AA}$ or $\mathrm{Hb} \mathrm{AS}$ children (siblings of the patients) was also studied. Each individual in the study had a thorough physical examination and a review of clinical records to document any previous episodes of bacterial infections that required hospitalization.

The $\beta^{s}$-globin gene cluster haplotype and $\alpha$-globin genotype were determined in all patients using standard methods $[10,11]$. Liver/spleen scintigraphs were obtained with ${ }^{99 \mathrm{~m}} \mathrm{Tc}$-labeled tin colloid (Amersham) in the patients [11]. Radionuclide images of the posterior, left lateral and anterior views of the splenic area were obtained. The results were graded as normal (group 1) if the splenic visualization was of the same intensity as the liver image, partial (group 2) if there was a decrease in the splenic image or no visualization (group 3). Serum IgG, IgA and IgM levels and IgGScs were quantitated using nephelometry (Beckman) [12, 13]. The quantitation was repeated at least a month after the last determination in any individual with an abnormally high or low level. In such cases, the average level was used for calculations.

Data are presented as means \pm SE except where otherwise stated. Student's $t$ test or analysis of variance (ANOVA) was used, where appropriate, to test the statistical significance of differences between the mean values in different groups. Pearson's correlation coefficients were computed to examine the relationship between variables.

\section{Results}

Twenty-nine SS patients (20 males and 9 females) aged 2-16 years (mean \pm SD $7.6 \pm$ 3.4 years) were studied. The control group consisted of 34 individuals (18 males and 16 females) aged $1-15$ years (mean \pm SD $5.8 \pm$ 3.4 years) of whom 25 were $\mathrm{Hb} \mathrm{AA}$ and nine were $\mathrm{Hb}$ AS genotype.

Twenty-three (79.3\%) SS patients were homozygous for the SAI haplotype and 6 (20.7\%) were compound heterozygotes for this and the Benin haplotypes. Hb F levels ranged from 6 to $30.6 \%$ with a mean of 20.3 $\pm 6.6 \%$

The $\alpha$-globin genotype was successfully determined in all SS patients. Seventeen (58.6\%) had their full complement of $4 \alpha$-globin genes $(\alpha \alpha / \alpha \alpha), 8(27.6 \%)$ were $\alpha$-thal-2 heterozygotes $(-\alpha / \alpha \alpha)$, and $4(13.8 \%)$ were homozygotes $(-\alpha /-\alpha)$.

Among the SS patients, 10 (34.5\%) had palpable spleens of $2-8 \mathrm{~cm}$ below the costal margin. Liver/spleen scintigraphy was successfully performed in 23 patients of whom 10 (43.5\%) had normal visualization (group 1), $6(26.1 \%)$ had partial visualization (group 2) and 7 (30.4\%) had no visualization (group 3). 
Table 1. Mean ( $\pm \mathrm{SE})$ serum immunoglobulin values in SS patients

\begin{tabular}{llll}
\hline Group & IgG, g/l & IgA, g/l & IgM, g/l \\
\hline SS $(n=29)$ & $14.38 \pm 0.7$ & $2.25 \pm 0.2$ & $1.48 \pm 0.1$ \\
Group 1 $^{1}(\mathrm{n}=10)$ & $12.06 \pm 1.0$ & $2.25 \pm 0.4$ & $1.82 \pm 0.2$ \\
Group 2 $^{1}(\mathrm{n}=6)$ & $13.85 \pm 1.8$ & $2.08 \pm 0.5$ & $1.28 \pm 0.2$ \\
Group 3 $^{1}(\mathrm{n}=7)$ & $18.60 \pm 0.8$ & $2.49 \pm 0.6$ & $1.23 \pm 0.2$ \\
Controls $(\mathrm{n}=34)$ & $11.84 \pm 0.5$ & $1.42 \pm 0.1$ & $1.25 \pm 0.1$
\end{tabular}

Grouped according to splenic scintigraphy results (see text).
Table 1 shows the mean immunoglobulin concentrations in the patients and controls. The individual values of $\mathrm{IgG}, \operatorname{IgA}$ and $\mathrm{IgM}$ were within the normal range for our lab, except for 7 patients who had excessively high $\mathrm{IgG}$ values. There was no significant sex difference in the values except for IgM which was significantly $(\mathrm{p}<0.05)$ higher in females $(1.80 \pm 0.3 \mathrm{~g} / \mathrm{l})$ than in males $(1.30 \pm 0.1 \mathrm{~g} / \mathrm{l})$. There was no significant correlation of the immunoglobulin classes with age or $\mathrm{Hb} F$ level. There was no significant difference in the mean values of the three immunoglobulin classes in those with or without palpable spleens, irrespective of (splenic) size. Also the individual values of IgScs were within the normal range for the population. Among the control subjects, there were no significant sex differences in the mean immunoglobulin values, and no correlation with age could be demonstrated.

When the values were compared according to splenic scintigraphy, there was a striking linear increase in IgG from group 1 to 3 (table 1), with significant differences in the mean values of the three groups (ANOVA F $=8.50$, $\mathrm{p}=0.002$ ). The difference between the means of groups 1 and 3 was also highly significant $(\mathrm{p}<0.001)$. On the other hand, there was a linear decrease in mean IgM from group 1 to group 3, but the difference was not significant $(\mathrm{F}=2.37, \mathrm{p}=0.12)$. IgA did not demonstrate $\mathrm{a}$

Immunoglobulins in Sickle Cell Anemia linear pattern. Of the 23 patients who had splenic scintigraphy, $15(65.2 \%)$ had never been hospitalized for a bacterial infection, 6 (26.1\%) had had one episode and 2 (8.7\%) who were both SAI homozygotes and who belonged to group 3 had had more than two episodes each. None of the remaining 5 patients who did not have scintigraphy performed had been hospitalized for severe bacterial infections. None of the controls had a palpable spleen and none had been hospitalized for severe bacterial infection.

When the immunoglobulin values were stratified according to the patients' $\alpha$-globin genotypes, mean IgG values showed a linear decrease from group 1 to 3 (table 2), a reverse of which was seen when splenic scintigraphy was used to stratify the group. However, the differences among the mean values were not significant $(\mathrm{F}=1.07, \mathrm{p}=0.35)$. There was no linear trend among the values for IgA or IgM in the three groups and the differences between the mean values were not significant.

IgGScs were determined in $17 \mathrm{SS}$ and 21 control subjects. There was no significant difference in the mean values between the two groups (table 3). However, when the SS population was classified according to splenic scintigraphy, the values for $\mathrm{IgG} 1$ and $\mathrm{IgG} 3$ were significantly higher $(p<0.01)$ in group 3 when compared to group 1,2 or the controls. The mean values of each IgGSc in group 1 or 2

Med Principles Pract 1999;8:183-188 185 
Table 2. Mean ( \pm SE) serum immunoglobulin values in SS patients with different $\alpha$-globin genotypes
Table 3. Mean ( \pm SE) $\operatorname{IgG}(\mathrm{g} / \mathrm{dl})$ subclasses in SS patients and controls
Table 4. Mean ( \pm SE) $\operatorname{IgG}(\mathrm{g} / \mathrm{dl})$ subclasses in SS patients with different $\alpha$-globin genotypes

\begin{tabular}{lllll}
\hline $\begin{array}{l}\text { Group } \\
\text { genotype }\end{array}$ & IgG, g/l & IgA, g/l & IgM, g/l \\
\hline 1 & $\alpha \alpha / \alpha \alpha(\mathrm{n}=17)$ & $15.14 \pm 1.1$ & $2.23 \pm 0.3$ & $1.54 \pm 0.3$ \\
2 & $-\alpha / \alpha \alpha(\mathrm{n}=8)$ & $13.03 \pm 1.3$ & $2.41 \pm 0.5$ & $1.56 \pm 0.5$ \\
3 & $-\alpha /-\alpha(\mathrm{n}=4)$ & $12.83 \pm 1.3$ & $2.05 \pm 0.4$ & $1.06 \pm 0.4$ \\
\hline
\end{tabular}

\begin{tabular}{lrlll}
\hline Group & \multicolumn{1}{l}{ IgG1 } & IgG2 & IgG3 & IgG4 \\
\hline SS $(\mathrm{n}=17)$ & $8.29 \pm 0.6$ & $2.21 \pm 0.2$ & $0.84 \pm 0.1$ & $0.68 \pm 0.1$ \\
Group 1 $^{1}(\mathrm{n}=8)$ & $7.54 \pm 0.4$ & $2.08 \pm 0.3$ & $0.69 \pm 0.1$ & $0.45 \pm 0.1$ \\
Group 2 $^{1}(\mathrm{n}=4)$ & $6.00 \pm 0.8$ & $2.14 \pm 0.5$ & $0.45 \pm 0.1$ & $1.07 \pm 0.2$ \\
Group 3 $^{1}(\mathrm{n}=5)$ & $11.67 \pm 0.6$ & $2.42 \pm 0.4$ & $1.28 \pm 0.2$ & $0.88 \pm 0.1$ \\
Controls $(\mathrm{n}=21)$ & $8.19 \pm 0.5$ & $2.21 \pm 0.2$ & $0.80 \pm 0.1$ & $1.49 \pm 0.9$
\end{tabular}

See table 1 .

\begin{tabular}{llllll}
\hline $\begin{array}{l}\text { Group } \\
\text { genotype } \\
\text { g-Globin }\end{array}$ & IgG1 & IgG2 & IgG3 & IgG4 \\
\hline 1 & $\alpha \alpha / \alpha \alpha(\mathrm{n}=17)$ & $9.61 \pm 0.7$ & $2.03 \pm 0.3$ & $0.89 \pm 0.2$ & $0.73 \pm 0.1$ \\
2 & $-\alpha / \alpha \alpha(\mathrm{n}=8)$ & $7.45 \pm 0.5$ & $2.39 \pm 0.3$ & $0.69 \pm 0.2$ & $0.52 \pm 0.1$ \\
3 & $-\alpha /-\alpha(\mathrm{n}=4)$ & $5.15 \pm 1.2$ & $2.51 \pm 0.4$ & $0.92 \pm 0.1$ & $0.81 \pm 0.4$ \\
\hline
\end{tabular}

were not significantly different from the mean value in the controls. ANOVA showed that the differences in the mean values in the three groups were significant for $\operatorname{IgG} 1(\mathrm{~F}=22.9, \mathrm{p}=$ $0.00001), \operatorname{IgG} 3(\mathrm{~F}=6.65, \mathrm{p}=0.009)$ and $\mathrm{IgG} 4$ $(F=6.09, p=0.01)$. There were no significant age or sex differences in both the patient and control groups, and the values among the SS patients were not influenced by splenic size or $\mathrm{Hb} F$ level.

Table 4 shows the mean values of the IgGScs when the SS group was stratified according to $\alpha$-globin genotypes. A significant linear decrease was noticed from group 1 to 3 for $\operatorname{IgG1}(\mathrm{F}=5.7, \mathrm{p}=0.013)$. A similar relationship was not demonstrated for $\operatorname{IgG} 2$, IgG3 or IgG4.

\section{Discussion}

The clinicopathological features of SS disease are heterogeneous, and several ameliorating factors have been identified, including

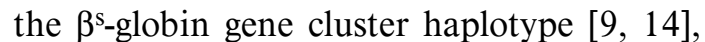
coexistent $\alpha$-thal trait [15], level of $\mathrm{Hb} \mathrm{F}$ and 
female gender [16]. The SAI and Senegal haplotypes, unlike Bantu and Benin, are associated with mild disease probably because homozygotes and compound heterozygotes have high $\mathrm{Hb} \mathrm{F}$ usually in the range of 15 to more than $30 \%$. Kuwaiti SS patients are mostly SAI homozygotes [10] and, in addition, they have a high prevalence of $\alpha$-thal trait, estimated at about $30-40 \%[11,17]$. It is therefore not surprising that, as has been reported for SS patients from Eastern Saudi Arabia, our patients have a low incidence of severe bacterial infections and recurrent infarction. In the present study, the mean $\mathrm{Hb} \mathrm{F}$ was $20.3 \%$, and $41.4 \%$ had coexistent $\alpha$-thal trait (either as homo- or heterozygotes).

It is interesting that the most important factor associated with a high IgG level in the present study is a poor splenic function as identified by nonvisualization on scintigraphy. This is also the group of patients who have had frequent severe bacterial infections. It would, therefore, appear that stimulation from recurrent infections is the real determinant of high IgG in SS patients with SAI haplotype. Conversely, IgM was lowest in patients with no splenic visualization, which is in keeping with previous reports that IgM is only increased when there is a demonstrable functional splenic tissue [1]. It is also low in individuals who have been surgically splenectomized [1]. The increased levels of IgG1 and $\mathrm{IgG} 3$ in group 3 in the present study are probably related to the overall increase in $\mathrm{IgG}$. This finding corroborates the report by Hedo et al. [6] from Nigeria, who documented increased IgG1 and IgG3 among their patients with a high severity index.

A previous study from our center demonstrated that SS patients with coexistent $\alpha$-thal trait are more likely to retain normal splenic function [11]. It is therefore not surprising that coexistent $\alpha$-thal was shown in the present study to have an influence on serum
IgG and IgG1 levels. On the other hand, the $\mathrm{Hb} F$ level does not influence immunoglobulin and IgGSc levels in our SAI SS patients.

While most of our patients did not have severe or recurrent infections, 2 (aged 7 and 11 years, respectively) SAI homozygotes among them had had five episodes of pneumonia, 3 of acute osteomyelitis, 2 of pyelonephritis, 1 lung abscess and 1 septicemia complicated by disseminated intravascular coagulopathy. Both had no splenic colloid uptake on scintigraphy and had the highest levels of serum IgG. Interestingly, one of them had the lowest $\mathrm{IgG} 2$ value $(0.76 \mathrm{~g} / \mathrm{dl})$ among the patients; the normal range for our lab being $0.74-3.42 \mathrm{~g} / \mathrm{dl}$. This particular patient has been followed up for 2 years since the study concluded and her IgG2 continued to fall.

It is interesting that the mean serum $\mathrm{IgG}$, IgA and IgM values obtained in the present study were not significantly different from those in the previous studies $[3,8]$ of SS patients from Eastern Saudi Arabia (17.82 \pm $4.2,2.19 \pm 0.7$ and $1.62 \pm 0.4 \mathrm{~g} / \mathrm{dl}$, respectively) and America (13.9 $\pm 0.6,2.23 \pm 0.3$ and $1.7 \pm 0.1 \mathrm{~g} / \mathrm{dl}$, respectively), even though the latter were mostly of the Benin chromosomal haplotype background. However, the corresponding values in a group of Nigerian SS patients [8] were $23.15 \pm 1.0,2.60 \pm 0.2$ and $5.45 \pm 1.5 \mathrm{~g} / \mathrm{dl}$, respectively, showing grossly elevated IgG and IgM. This pattern has been attributed to an environmental factor, possibly a chronic or a recurrent malaria since the malaria parasite is a known mitogen that stimulates the B cell system [18]. Indeed, a direct relationship was demonstrated between malaria antibody titers and immunoglobulin levels among Nigerian SS patients [8].

In conclusion therefore, physicians looking after SS patients with the SAI haplotype should realize that a subset of these patients will present with a severe clinical course and 
fulminant bacterial infections. Investigations should include splenic scintigraphy, $\alpha$-globin genotyping, serum immunoglobulin and $\operatorname{IgG}$ subclasses. It is only after all these investigations that the patient and his/her family can be adequately counseled about the likelihood of frequent bacterial infections.

\section{Acknowledgment}

The authors wish to thank Mr. B.S. Srivastava, Department of Pediatrics, Kuwait University, for his technical assistance. This study was supported by the Kuwait University Research Grants MK031 and MK034.

\section{References}

1 Gavrilis P, Rothenberg SP, Guy R Correlation of low serum IgM levels with absence of functional splenic tissue in sickle cell disease syndromes. Am J Med 1974;57:542_ 545.

2 De Ceular K, Forbes M, Maude GH, Pagliucca A, Serjeant GR: Complement and immunoglobulin levels in early childhood in homozygous sickle cell disease. J Clin Lab Immunol 1986;21:37-41.

3 Al-Awamy BH, Niazi GA, Al-Mouzant MI, Al-Nahdi M, Naeem MA, Sumer T: Serum immunoglobulin and complement levels in patients with sickle cell anaemia from eastern province of Saudi Arabia. Trop Geogr Med 1988;40:13-16.

4 Cetiner S, Akoglu TF, Kilinc Y, Akoglu E, Kumi M: Immunological studies in sickle cell disease: Comparison of homozygous mild and severe variants. Clin Immunol Immunopathol 1989;53:32-39.

5 Adeodu OO, Adekile AD, Jeje AA, Adedeji FA: Serum immunoglobulins $\mathrm{A}$ and $\mathrm{M}$ in sickle cell patients from Ile-Ife, Nigeria. East Afr Med J 1989;66:631-635.

6 Hedo C, Aken'Ova Y, Okpala I, Salimonu LS: Serum immunoglobulin (A, G, M) classes and IgG subclasses in sickle cell anaemia. APMIS 1993; 101:353-357.
7 Natta CL, Outschoorn IM: IgG2 deficiency in sickle cell anaemia. Scand J Haematol 1984;33:129134.

8 Adekile AD, McKie KM, Adeodu OO, Sulzer AJ, Liu JS, McKie VC, Kutlar F, Ramachandran M, Kaine W, Akenzua GI, Okolo AA, Asindi AA, Obinyan EA, Ogala M, Ibrahim M, Huisman THJ: Spleen in sickle cell anemia. Comparative studies of Nigerian and American patients. Am J Hematol 1993;42:316-321.

9 Powars DR: Sickle cell anemia: $\beta^{\text {s- }}$ Gene cluster haplotypes as prognostic indicators of vital organ failure. Semin Hematol 1991;28:202-208.

10 Adekile AD, Gu L-H, Baysal E, Haider MZ, Al-Fuzae L, Aboobacker KC, Al-Rashied A, Huisman THJ: Molecular characterization of $\alpha$-thalassaemia determinants, $\beta$ thalassaemia alleles and $\beta^{\text {s }}$ haplotypes among Kuwaiti Arabs. Acta Haematol 1994;92:176-181.

11 Adekile AD, Tuli M, Haider MZ, Al-Zaabi L, Al-Mohannadi S, Owunwanne O: Influence of $\alpha$-thalassemia trait on spleen function in sickle cell anemia patients with high HbF. Am J Hematol 1996;53:1-5.

12 Buffone GJ: Immunonephelometric and turbidometric measurement of specific plasma proteins; in Rose NR, Friedman H (eds): Manual of Clinical Immunology, ed 2. Washington, American Society of Microbiology, 1980.
13 Killingworth LM, Savory J: Nephelometric studies of the precipitin reaction: A model system for specific protein measurement. Clin Chem 1980;19:403-407.

14 Greenwood BM, Vick RM: Evidence for a malaria mitogen in human malaria. Nature 1975;56:592594.

15 Embury SH, Lark MR, Monroy G, Mohandas N: Concurrent sickle cell anemia and $\alpha$-thalassemia: Effect on pathologic properties of sickle erythrocytes. J Clin Invest 1984;73:116123.

16 Steinberg MH, Hsu H, Nagel RL, Milner PF, Adams JG, Benjamin L, Fryd S, Gillette P, Gilman J, Josifovska $\mathrm{O}$, Hellman-Erlingsson S, Safaya S, Huey L, Rieder RF: Gender and haplotype effects upon hematological manifestations of adult sickle cell anemia. Am J Hematol 1995;48: 175-181.

17 Adekile AD, Haider MZ: Morbidity, $\beta^{s}$ haplotypes and $\alpha$-globin gene patterns among sickle cell patients in Kuwait. Acta Haematol 1996;96: 150-154.

18 Greenwood BM, Vick RM: Evidence for malaria mitogen in human malaria. Nature 1975;56:592-594. 